\title{
CULTIVATION OF MEDICINAL PLANTS BY SMALLHOLDER FARMERS IN SOUTH AFRICA: CONSTRAINTS TO COMMERCIALIZATION
}

\author{
Christopher Ugochukwu Nwafor
}

\author{
Department of Agriculture, Central University of Technology, South Africa
}

manchrizzo@hotmail.com

\begin{abstract}
South Africa has an abundant heritage of valuable indigenous plants with recognized medicinal value. The reported critical over-harvesting of wild populations is considered an urgent issue for biodiversity conservation. Growing demand for therapeutic products from indigenous medicinal plants have led to increased interest in its cultivation. Cultivation of these indigenous medicinal plants represent a viable option for improving smallholder farmers' livelihoods, as well as sustaining the availability of these resources for future generations. Serious bottlenecks however exists for subsistent farmers in the cultivation of these valuable plants. It was pertinent to probe whether the cultivation of medicinal plants provide feasible solutions to rural poverty, while effectively conserving threatened indigenous biodiversity. The paper employed a comprehensive review of existing literature to explore relevant issues constraining smallholder farmers from involvement in a potentially lucrative medicinal plants value-chain. Findings indicate challenges such as inadequate domestication of valuable plants species, continued over-harvesting from wild populations, poor knowledge of required agronomic practices, low efficacy perception regarding derivatives from cultivated plants, among a multitude of others. These constraints exists alongside the conservation-oriented strategy driven by international conservation agencies and wholly adopted by the South African government. Recommendations to improve smallholder involvement in the cultivation of medicinal plants include support to research and extension, targeted inducement to smallholders, contracting and off-take agreements, aimed at promoting an alternative poverty-alleviation-focused economic development strategy. The review adds to the conceptual discourse related to plant diversity, resource conservation, poverty alleviation and economic development within the medicinal plants valuechain.
\end{abstract}

Keywords: conservation, biodiversity, medicinal plants, smallholder farmer, strategy.

\section{Introduction}

The importance of medicinal plants have been ascribed to their ancient therapeutic uses, as well as relevance to human culture and nutrition (Anthonio et al., 2013; Chen et al., 2016; Mahmoudi, 2017). These plants have been shown to have a long and illustrious history among many indigenous peoples and communities (Kumar and Bhatnagar, 2014; Panday and Singh, 2016; Lerotholi et al., 2017). Medicinal plants contain substances useful for healing purposes, or which are easily blended for pharmaceutical purposes. Through secondary metabolism, medicinal plants produce a diverse array of biologically active compounds (Cushnie et al., 2014) credited with several pharmacological properties. A vast number of medicinal plants have been studied regarding their phytochemical constituents (Egamberdieva et al., 2017), including those commonly used in the treatment or prevention of specific ailments and diseases, and generally considered to play a beneficial role in health-care. Their application in the treatment of humans and 
livestock for various ailments and diseases have been well documented, as local plants used for medicinal purposes possess biological and sociocultural legacies (Mbuni et al., 2020; Sher et al., 2016).

The cultivation, harvesting, processing, utilization and marketing of medicinal plants make valuable contributions to the economic well-being of communities (Bareetseng, 2015; Sher and Bankworth, 2015; Rousan and El-Uzaizi, 2016), while also developing new value-chains and the traditional health-care knowledge systems. Medicinal and aromatic plants are also categorized as essential constituents of non-timber forest products, which are used in traditional health-care interventions while supporting the livelihoods of many across the globe. Estimates indicate that approximately $80 \%$ of the global population depend on traditional medicines (Shakya, 2016), with a projected market value in excess of USD 72 billion (Rathore and Mathur, 2018).

According to Agribook Digital (2020), medicinal plant farms are considered as frontrunners for the future provision of scarce and commercially valuable plant species with medicinal value in Southern Africa. There is however insignificant cultivation of medicinal plants in South Africa (DAFF, 2016; Moshi and Mhame, 2013), with only few plants minimally cultivated such as Moringa oleifera and Aloe forex. Considering the market potential and the shortfall from natural or wild sources, many international organizations including the World Health Organization (WHO), International Union for the Conservation of Nature (IUCN) and World Wide Fund (WWF), have argued that commercial cultivation provides a good alternative source and enduring livelihood for local communities, including protection of the natural resource base (Rashid et al., 2014). Related closely to this, Ndou et al. (2019) explored the implications of a functional medicinal plants valuechain in South Africa, specifically linked to the viability and sustainability of smallholder farmers' involvement. They outlined the entry constraints for smallholder farmers into the lucrative niche, while advocating for the provision of necessary support to enable participation in the cultivation and processing of medicinal plants by rural producers. Cultivation of medicinal plants is considered as a feasible diversification enterprise for many small-scale farmers as demand is high, trade opportunities are increasing and the income generating potential is good (Marshall, 2011).

However, very few studies have explored the challenges of medicinal plants cultivation and commercialization among smallholder producers. There are myriad of risks and challenges inherent in the domestication of medicinal plants, which Volenzo and Odiyo (2020) claimed to require additional comprehension. Astutik et al. (2019) considered this an amplification of the need for empirical investigation of medicinal plants production systems. This review therefore aims to highlight the constraints related to the cultivation of valuable medicinal plants among rural smallholder producers in South Africa. The current paper differs from available studies on the cultivation of medicinal plants, by plugging existing gaps related to the involvement of small scale farmers, which is deemed relevant for policy makers, agricultural development practitioners and smallholder farmers interested in the cultivation of medicinal plants as a rural livelihoods approach, a targeted 
strategy for poverty alleviation, and for increasing income generation opportunities respectively.

The paper is structured according to the following sections; a methodological outline is presented in the next section. Section 3 provides a review of medicinal plants' uses and its importance to rural livelihoods while identifying current studies specifically related to the cultivation of medicinal plants in South Africa. Section 4 outlines and discusses the key issues established in the literature related to cultivation of medicinal plant. Section 5 concludes the review with a summary and recommendations.

\section{Method}

Extensive literature search using web-based database especially Google Scholar were conducted between May and November 2020. Other databases consulted include EBSCO-Host and Web of Science, utilizing the search words 'medicinal plants', 'cultivation of medicinal plants', 'medicinal plants in South Africa' and 'cultivation of medicinal plants in South Africa'. These searches yielded a variety of articles which were synthesized based on relevance and limited to those published in peer-reviewed journals. Articles published between 2000 and 2012 were consulted to understand the context for medicinal plants cultivation, though only those recently published between 2014 and 2020 were adopted and used in the study. Information from these sources were used to analyze issues relevant for smallholder involvement. Additional insights were provided on practices in other countries related to cultivation of medicinal plants.

\section{Review}

\section{Usefulness of medicinal plants in South Africa}

In South Africa, medicinal plant-based formulations locally called 'muthi' in the isiZulu language and 'amayeza' in isiXhosa language are widely used in the health-care system, particularly by the indigenous African population. In many rural communities where primary health care systems and livestock veterinary services are not easily accessible, there is reliance on indigenous medicinal plants. Opara and Osayi (2016) posited that in the face of systemic challenges, herbal medicine presents a viable alternative in largely pluralizing health systems. Furthermore, medicinal plants are the backbone of an array of ethno-veterinary and traditional medical systems all over the world (Dar et al., 2017; Oluwafemi et al., 2020), as they provide locally accessible, culturally appropriate, and economically affordable healthcare options (Diaz-Reviriego et al., 2016).

There is significant trade in the South African traditional medicine sector exceeding R2.9 billion annually (Mander et al., 2007). The linkages between bio-cultural diversity and abundance of plant species in South Africa provides impetus for extant interventions to develop traditional medicines. Medicinal plants are vital in the modern complementary and alternative medicines sector, and facilitates the discovery of novel drug contenders in the pharmaceutical sector (Shakya, 2016). Medicinal plants also play a central role not only as traditional medicines but as trade commodities, and the livelihood contribution 
these goods make to a large number of rural communities has been noted (Rankoana, 2016). With increasing population growth, urbanization and strong cultural values regarding traditional medicines, the trade in medicinal plants has surged considerably (DAFF, 2016; Xego et al., 2016). This has resulted in the over-harvesting of certain important species found in the wild, to the point of certain extinction. For instance, medicinal plants such as Siphonochilus Aethiopicus (Zingiberaceae) commonly called 'wild ginger' is widely considered as an endangered species on the Red Data List, with a variety of uses for which the Botanical Society of South Africa has actively encouraged farmers to cultivate. Significantly, the tubers of Pelargonium sidoides and Pelargonium reniforme are considered important medicinal species, a rich source of vital ingredients with useful properties, which have been harvested from wild populations for the export market. With virtually negligible field cultivation, the pressure on existing naturally occurring populations and resulting depletion presents a looming threat to biodiversity (Innovus, nd).

Both empirical and anecdotal evidence indicate the entrance of medicinal plant products into the informal and formal entrepreneurial sectors of the South African economy (Wiersum et al., 2006), which Tanga et al. (2018) referred to as a large and growing industry. This has led to an increase in the numbers of wild plant harvesters, backyard medicinal plant gardens, and small holdings of selected medicinal plants, cottage processors and traders. An entire value chain for medicinal plants has developed to meet the needs of many millions traditional-remedy consumers in Southern Africa (Petersen et al., 2017). Evidently, the demand for medicinal and aromatic plants have grown rapidly because of accelerated local, national and international interest. According to DAFF (2016) this interest resulted in the export of approximately 6497 tons of medicinal plants in 2015. Noorhooseini et al. (2017) attributed this to a global trend of increased acceptance of herbal products especially in developed countries, and the involvement of western pharmaceutical industry. The demand is expected to grow significantly in the future fuelled by the growth in sales of herbal supplements and remedies.

\section{Related studies on cultivation of medicinal plants in South Africa}

Scholars and researchers earlier highlighted the importance of cultivating medicinal plants in South Africa (Jagar and Staden, 2000; Keirungi and Fabricius, 2005; Wiersum et al., 2006). This was considered both a conservation strategy and poverty reduction plan, inherited from rural development thinking. The conservation-through-cultivation approach (Mcgaw et al., 2005) continues to be a predominant framework, guiding recent policies and strategy related to medicinal plants. Recent studies on the cultivation of medicinal plants have also primarily adopted the conservation approach, either to highlight value-chain interactions, sustainability and quality assurance issues ( Tanga et al., 2018; Ndou et al., 2019), identified abiotic conditions or reviewed strategies for cultivation (Xego et al., 2016; Tshabalala et al., 2020), compared benefits from wild and cultivated medicinal plants (Van Wyk et al., 2018), or documented local knowledge and practices among segments of the population (Semenya and Potgeiter, 2014; Maroyi, 
2017). Specific studies related to constraints facing smallholder farmers in cultivating medicinal plants are scant. Keirungi and Fabricius (2005) earlier averred that the main barriers to commercial cultivation are availability of suitable land, irrigation facilities, lack of start-up capital, inadequate access to markets and unavailability of seeds or propagation materials. They also opined that cultivation of medicinal plants could contribute to the economic empowerment of women in rural areas. However, Volenzo and Odiyo (2020) pointed to the low benefits for growers of medicinal plants even in the face of increasing international trade, and attributed this to existing non-tariff barriers -such as health and safety requirements, and high transactional costs.

Ndou et al. (2019) investigated the medicinal plants value-chain in South Africa, and identified the various actors involved in the sector. Their study highlighted existing relationships among the different role players in the medicinal plants trade, characterized by processing and trade, with entry difficulties for smallholder producers. Tanga et al. (2018) explored the cultivation of medicinal plants in South Africa with an emphasis on the quality assurance and sustainability of supply. They pointed out the scarcity of information on this topic, which they blamed on attention being paid to food crops and food security issues. Their study mostly dwelt on issues of propagation, bio-diversity conservation, sustainability of supply, product quality and commercialization. The study however, identified pertinent issues including accessibility of plant materials, disease susceptibility, labor cost, environmental and agronomic adaptation issues facing potential entrants in the cultivation of medicinal plants. Xego et al. (2016) investigated the methods suitable for growing medicinal plants, though they specifically concentrated on hydroponics as a cultivation strategy. While concluding on the positive income generating potential, their review did little to highlight possible constraints to smallholder involvement in medicinal plant cultivation.

Semenya and Potgieter (2014) documented some of the medicinal plants and indigenous knowledge among the Bapedi tribe, and observed that traditional healers cultivated scarce medicinal plants in backyard home-gardens. Their study however, focused on the identification of medicinal plants found in home-gardens within their study area. Van Wyk and Prinsloo (2018) explored the harvesting, sustainability and cultivation of medicinal plants, outlining inherent advantages in cultivating rather than wild harvesting of medicinal plants. They identified challenges to the cultivation of medicinal plants, requiring a shift from traditional harvesting to planned cultivation for formal markets. Maroyi (2017) identified some of the wild and cultivated plant species useful for medicinal purposes in the Eastern Cape Province, while primarily focused on diversity of use and local knowledge among study respondents. Tshabalala et al. (2020) used analytical modelling to predict the spatial suitability distribution of Moringa oleifera cultivation, and concentrated on soil and other conditions favorable for maximum growth of the plant. Considered generally, these studies are favorably aligned to the school of thought promoting cultivation as a purely conservation strategy. 


\section{Discussion}

The exploration of available literature on cultivation of medicinal plants in South Africa revealed pertinent issues relevant for decision makers or smallholder farmers. Firstly, medicinal plants cultivation in South Africa has been promoted by policy makers mainly as a conservation strategy. Secondly, there are a multitude of agronomic and agroecological issues that present considerable hindrance to cultivating medicinal plants, especially for smallholder farmers. Finally, a host of complex socio-economic and sociocultural considerations needs to be resolved before any progress can be attained involving South African smallholder farmers in the medicinal plants value-chain. These issues are further discussed below.

\section{Medicinal plants cultivation as a conservation strategy}

The position taken by differing schools of thought regarding what might be considered a better conservation strategy represent significant hurdles. While a number of agencies are recommending that wild species be brought into cultivation systems, others have argued that sustainable harvesting presents a better approach for most wild-harvested species (Dzerefos et al., 2016). This discourse considers the contributions made to local economies by medicinal plants and their greater value to harvesters over the long term. The crux of this argument is whether medicinal plants conservation should ideally happen in nature or in the nursery, or even both (Schipmann et al., 2006; Xego et al., 2016). Cultivation can have conservation impacts, positive or negative, either reducing the extent to which wild populations are harvested, or lead to environmental degradation and loss of genetic diversity as well as loss of incentives to conserve wild populations. The relationship between in situ and ex situ (in-domo) conservation of medicinal plant species is an interesting topic with significant implications, though it is beyond the scope of this review. Identifying the conservation benefits and costs of the different production systems will continue to guide policies.

Tanga et al. (2018) highlighted that the cultivation of medicinal plants falls primarily within the domain of biodiversity conservation, while enhancing quality assurance and increases the availability of medicinal plants for commercialization. It therefore has both primary and secondary objectives. Among proponents of cultivation as a conservation strategy, propagation of medicinal plants also come with risks especially for traditional healthcare and cultural practices (Dzerefos et al., 2016). These risks include issues of acceptability and efficacy of the commercially propagated plant materials. For threatened medicinal plant species, commercial cultivation is seen as a conservation option, while for all other harvested species the priority conservation option is sustainable harvesting from wild populations. This represents the strongly held view-point among many conservationists.

The disagreement regarding the potential benefits between in situ preservation and in domo conservation strategies, do not take into account the absence of established cultivation practices for many indigenous medicinal plants, especially those facing threats of over-harvesting and extinction. This will therefore entail the introduction of these 
medicinal plant species into existing farming systems. A transformational agenda involving a rethink and reframe of strategy related to the cultivation of medicinal plants will introduce required fundamental changes. These changes need to pay greater attention to integrating social, economic and environmental sustainability issues in the medicinal plants sector. This position reflects a growing synergy between effective biodiversity conservation and poverty reduction efforts (Craven et al., 2019).

\section{Agronomic and agro-ecological issues}

For medicinal plants to be successfully cultivated by smallholder farmers, these plants need to be domesticated. This involves the modification of the plants' morphological characteristics and genetic make-up, and possible adjustments to the physical environment in which the plant is grown,-especially for greenhouse cultivation. The domestication of plants previously found in the wild involves their adaptation to a socially managed environment (Wiersum et al., 2006). Proper crop cultivation techniques needs to be developed by crop scientists, and the transfer of scientifically developed domestication technology and procedures to potential growers by agricultural extensionists.

Chen et al. (2016) raised issues related to yield and potency of domesticated medicinal plants, which requires the application of bio-technical approaches such as tissue culture, micro-propagation, synthetic seed technologies and molecular markers. These approaches aim to improve desirable characteristics of cultivated medicinal plants while reducing possibilities of misidentification and adulteration of critically endangered species. Strategic funding and partnerships are hence required with regards to this, and involves greater commitment from government agencies, international organizations and regulators as well as the scientific community.

Cultivation provides a number of advantages over wild stocks for the production of plantbased medicines, outlined in Van Wyk and Prinsloo (2018). These include reliable botanical identification, sustainable sourcing, pre-contact agreements on volume and price, quality control, standards according to regulations and preferences, product certification and homogeneity. Xego et al. (2016) pointed out the potential of using an alternative cultivation strategy such as hydroponics in the cultivation of medicinal plants. They observed the many reports of hydroponics cultivation producing more shoots than conventional soil cultivation, and relatively higher yields of bioactive fraction and total activity than from wild harvested plants. Giurgiu et al. (2014) earlier posited that cultivation using hydroponics improved the concentration of bio-active properties in medicinal plants. Successful cultivation of medicinal plants depends on diverse biotic and abiotic factors which can modulate the composition of secondary metabolites and essential oils. Also there seems to be a preference for organic or nature-based farming which as Egamberdieva and Teixeira (2014) outlined, is devoid of chemical fertilizers and pesticides. 
However, some common issues facing producers of medicinal plants include abundance and accessibility of wild populations in certain areas, agro-environmental conditions that are different from those in areas with naturally occurring plant populations, labor availability and costs, investments in machinery, post-harvest processing, and profitability of production (Dajic-Stevanovic and Pljevljakusic, 2015; Hishe et al., 2016).

\section{Socio-economic considerations}

Some researchers posit that for medicinal plants cultivation to be feasible economically and achieve scale, there is need for intensification of production within selected clusters of micro enterprise-based groups (Amujoyegbe et al., 2012). These plants have to be cultivated cheaply and in large quantities to generate profits for growers in the valuechain. Contrarily, though the main rationale for cultivation is economic feasibility, the limitations posed by uncontrolled harvesting from the wild will continue to drive prices lower. Cultivation for profit will hence be restricted to those plant species already on the brink of extinction, and useful for high-value medicinal preparations. Several challenges to the large scale cultivation of medicinal plants in South Africa are identified including, a lack of institutional support for production and dissemination of the propagation materials for important species, the low prices paid to harvesters, and long maturity periods for important medicinal plants (Van Wyk and Prinsloo, 2018). Others limitations include poor adaptation of plants in cultivated environments, their susceptibility to various pests and diseases, including high labor costs and low net returns (Tanga et al., 2018).

A number of studies have advocated for initiatives in South Africa to develop propagation and sustainable production methodologies. These proposed initiatives will ensure continuous availability and sustainable use of medicinal plant materials. In the absence of these propagation initiatives, Crouch and Smith (2011) envisaged limited progress and an ineffective implementation of sustainable conservation strategies for various overexploited medicinal species. Any effort to stimulate the commercial cultivation of medicinal plants, especially by smallholder farmers in rural communities, cannot gain traction without the financial, resource and human capital support from national government, provincial administration, municipalities and the private sector (Van Wyk and Prinsloo, 2018). These key players and sectors have been slow in promoting the valuechain, and this deferment makes it impractical and clearly uneconomical for increased smallholder involvement. Many smallholder farmers have faced difficulties accessing market information, wastage of valuable plant materials and subsequent abandonment of their projects.

The South African Department of Environment (DEFF, 2020) and report by the Small Enterprise Development Agency (2012) confirmed the limitation of smallholder farmers in the medicinal plants value-chain, with some subsistence cultivation of indigenous species by disadvantaged individuals. Most large scale cultivation, especially of rooibos and buchu species have been undertaken by large commercial farmers. Van Wyk and Prinsloo (2018) decried the potential for large-scale mono-cultural plantations established for export markets by external investors, which may alter market forces to their 
advantage, and restrict the social and economic development of small scale farmers. The commercial cultivation of medicinal plants in South Africa, therefore has the potential to widen the existing dichotomy (Nwafor and Westhuizen, 2020) between smallholders and commercial farmers. This portends the exclusion of smallholder farmers from participation, looming irrelevance of the strategy for livelihoods improvement and rural poverty alleviation.

Furthermore, cultivation of medicinal plants has the potential to deny current wild harvesters and traders any further participation in this income generating activity (Ndou et al., 2019), hence there is a reported disinclination among wild harvesters and traders to encourage any sustainable cultivation of commonly used medicinal plants (Van Wyk and Prinsloo, 2018). This situation reduces availability of highly south-after medicinal plants, with the scarcity of these plants having positive economic outcomes for traders and gatherers who benefit from resultant higher prices therein.

\section{Socio-cultural considerations}

For conservationists and some other social researchers, there is a continuous concern about the acceptance of cultivated medicinal plants (Moyo et al., 2015; Xego et al., 2016), as cultivated material is believed to lack spiritual power (Netshiluvhi and Ellof, 2016; Sanhokwe et al., 2016). Although cultivated medicinal plant material is accepted as an alternative in other countries, South African conservative traditional health practitioners believe that cultivated plants lack efficacy in healing. According to Fennel et al. (2004), cultivated medicinal plants may not have the same healing properties as those harvested from wild populations. Prinsloo and Nogemane (2018) however adduced factors such as season, irrigation and fertilization of material to possibly result in altered medicinal activity of cultivated materials. Furthermore, Schippmann et al. (2002) averred that bioactive compounds in fast growing cultivated stock may be lower than in wild populations because wild populations may be older due to slow growth.

However, this contention has been shown to be unfounded by Giurgiu et al. (2014), as the tissue-cultured method adopted in the propagation of Pelargonium sidoides produced materials of similar coumarin profiles to those existing in wild populations (Innovus, nd.). Contrarily, specific research regarding this issue reported cultivated medicinal plants possessing superior concentration of active molecules compared with those harvested from the wild (Aggarwal et al., 2014; Kamatchi and Vigneswari, 2018). Arguments regarding the preference of wild medicinal plants over cultivated ones, in terms of efficacy or possession of superior metabolites, were hence consigned to the realm of speculation and personal opinion devoid of scientific backing (Raghu and Amruth, 2018).

\section{Other hindrances to smallholder involvement}

Lubbe and Verpoorte (2011) as well as Schippmann et al. (2002) suggest that many plant species are not easy to cultivate, or are slow growing. Large investments are required before production can start and during the cultivation process. Cultivation of medicinal plants at a commercial scale also brings challenges such as pests and diseases 
(Mofokeng et al., 2020). Moeng and Potgieter (2011) however admitted that most critical species in the muthi trade can be successfully cultivated, if best-practice cultivation methods can be successfully pioneered on a large scale, which is a further obstacle to smallholder farmers. Misra (2009) also expressed concerns regarding ability of the cultivated medicinal plants to thrive in monocultures, and smallholders' capacity to meet the required production volumes. Furthermore, there is paucity of relevant knowledge among extension officers regarding commercially required types of medicinal plants, local sources of seeds or propagation materials, ideal soil requirements, and many other agronomic information that are mostly unavailable to smallholder farmers in South Africa.

\section{Legislative and policy bottlenecks}

South Africa is reported as one of the African countries with an existing national policy on the conservation of medicinal plants. However, the implementation of environmental legislation is hindered by the shared responsibility between national and provincial government. Strydom and King (2013) posits that this has resulted in a fragmented implementation of environmental laws, and failure to act against transgressors of the law. This loophole has been exploited by those harvesting critically endangered species and well as other medicinal plant species. Various international treaties such as the Convention for Biological Diversity and the Global Strategy for Plants Conservation, International Conservation of Nature (ICN) all emphasize sustainable harvesting from wild populations. The Food and Agriculture Organization (FAO) and World Health Organization (WHO) also recommends continued strengthening of legislation related to medicinal plants, while supporting the commercial cultivation of medicinal plants to benefit from the expanding global market of herbal medicines (Moshi and Mhame, 2013). These policy frameworks actively promote the conservation strategy for medicinal plants.

\section{Status of medicinal plants cultivation in other countries / continents}

There is very little commercial cultivation of medicinal plants by smallholder farmers in many Africa countries, similar to what is obtainable in South Africa. In Ghana, Appiah et al. (2019) averred that most of the medicinal plants used were collected from the wild, and are not under commercial cultivation. Ofori et al. (2012) also admitted a lack of cultivation, while suggesting commercial scale cultivation as a panacea to the reported scarcity or unavailability of more than 100 species. Though large scale cultivation of the medicinal plant Artemisia annua was reported in Kenya, Uganda and Tanzania; while in Benin, medicinal plant gardens have been established in different ecological zones (Gurib-Fakim, 2014), these are associated with research activities or government extension initiatives. There is limited progress in uptake of medicinal plants cultivation among small scale farmers. Recommendations for additional efforts in establishing home and botanical gardens for medicinal plants have been made.

On the international front, estimates suggest that between $1.3 \%$ and $3.3 \%$ only of the identified 2500 species traded are under cultivation (Rajeswara et al., 2012). Though India is a major exporter of medicinal plants, Raghu and Amruth (2018) posited that only 
a few species are actually cultivated, as emphasis is on collection from the wild. Cultivation in India is also considered a conservation effort aimed at maintaining natural stocks. However, Astutik et al. (2019) suggests the commercial cultivation trend is increasing in most countries of Asia. Reports indicate that cultivated species from private farmlands in China and Nepal contributed significantly to cash incomes for local farmers, constituting an estimated 32\% of total exports (Shenji et al., 2010; Kunwar et al., 2013). This has been attributed to the approach taken, wherein cultivation of medicinal plants is primarily aimed at improving local livelihoods (Williams et al., 2014; Negi et al., 2018). A livelihoods approach supported by a poverty-alleviation strategy towards the cultivation of medicinal plants, therefore provides a much needed impetus for smallholder farmers to participate in the commercial cultivation of medicinal plants.

\section{Conclusion}

The review showed that improving the livelihood of poor people, reducing the pressure on wild populations and enhancing biological diversity are the main reasons for promoting the cultivation of medicinal plants. Various constraints limit the participation of smallholder farmers which require concerted efforts towards resolution, from government, research and other interested stakeholders. As reported, a conservation-through-cultivation strategy currently drives efforts at cultivating medicinal plants. The implication is that any planned large scale cultivation of important indigenous medicinal plants by smallholder farmers will be a conservation-based decision. This decision helps to achieve biodiversity targets using an economic development approach. Involvement of smallholder farmers will therefore require inducements in the form of subsidies from provincial and national governments.

However, as shown in the case of some Asian countries, economic drivers need to be at the fore-front before conservation and biodiversity concerns. When considered from a livelihoods and poverty-reduction perspective, participation in cultivating medicinal plants will be attractive to smallholder farmers as there are clear economic benefits with potential for improved cash incomes for the household. This will require the elimination or reduction of various policy, price, research and extension obstacles currently faced by small-scale farmers in cultivating medicinal plants.

Two options are open for consideration towards involvement of smallholder farmers in the medicinal plants value-chain. First, a conservation-driven strategy aimed at sustainability of the plant species rather than an economic-based decision to improve the household incomes of smallholder farmers. This requires various forms of inducement from government, such as allocation of planting quotas, either by providing grants or subsidies per hectare planted by smallholder farmers. Secondly, a poverty elimination strategy driven by economic consideration places the smallholder farmer in the focus of all medicinal plants cultivation efforts. Various bottlenecks identified need to be reduced or eliminated. Contracting and off-take assurances contained within buy-back agreements between farmers and pharmaceutical companies or wholesale buyers should hence be put in place. 
Through the use of these non-mutually exclusive strategies, smallholder farmers can be sustainably involved in the commercial cultivation of medicinal plants, while supporting government to achieve both biodiversity conservation and economic development. There is considerable ambit for a win-win situation.

\section{References}

Aggarwal S., Sharma, N.G. and Anil, K.J. 2014. Studies on variation in elemental composition in wild and cultivated forms of Andrographis paniculata. International Journal of Chemical and Pharmaceutical Sciences, 5(2), 75-78.

Agribook Digital. (2020). Indigenous Medicinal Plants. Retrieved $8^{\text {th }}$ March 2020 from https://agribook.co.za/forestry-and-industrial-crops.

Amujoyegbe B.J., Agbedahunsi J.M. and Amujoyegbe O.O. 2012. Cultivation of medicinal plants in developing nations: means of conservation and poverty alleviation. International Journal of Medicinal and Aromatic Plants, 2(2), 345-353.

Anthonio G.D., Tesser C.D. and Moretti-Pires R.O. 2013. Contributions of Medicinal Plants to Care and Health Promotion in Primary Healthcare. Interface - Comunicação, Saúde, Educação, Botucatu, 17(46), 615 - 33.

Appiah K.S., Oppong C.P., Mardani H.K., Omari R.A., Kpabitey S. et al. 2019. Medicinal Plants Used in the Ejisu-Juaben Municipality, Southern Ghana: An Ethnobotanical Study. Medicines 2019, 6, 1; DOI: 10.3390/medicines6010001.

Astutik S., Pretzsch, J., Kimengsi, J.N. (2019). Asian Medicinal Plants' Production and Utilization Potentials: A Review. Sustainability, 11(19), 5483. DOI: 10.3390/su11195483

Bareetseng S. 2015. Community involvement in the commercialisation of medicinal plant species. The case studies: Lippia javanica and Elephantorrhiza elephantine. CSIR Presentation, 6 Nov, 2015.

Chen S.L., Yu H., Luo H.M., Wu Q., Li C.F., Steinmetz A. 2016. Conservation and Sustainable Use of Medicinal Plants: Problems, Progress and Prospects. China Medicine, 11, 37. DOI 10.1186/s13020-016-0108-7.

Craven D., Winter M., Hotzel K., Gaikwad J., Eisenhauer N., Hohmuth M., König-Ries B. and Wirth C. 2019. Evolution of interdisciplinarity in biodiversity science. Ecological Evolution, 9, 6744-6755.

Cushnie T.P., Cushnie B., and Lamb A.J. 2014. Alkaloids: an overview of their antibacterial, antibioticenhancing and anti-virulence activities. International Journal of Antimicrobial Agents, 44, 377-386. DOI:10.1016/j.jjantimicag.2014.06.001

DAFF- Department of Agriculture, forestry and Fisheries. 2016. A Profile of the South African Traditional Medicines Value Market Chain. Republic of South Africa.

Dajic-Stevanovic Z., Pljevljakusic D. 2015. Challenges and Decision Making in Cultivation of Medicinal and Aromatic Plants. In: Máthé Á. (eds) Medicinal and Aromatic Plants of the World. Springer, Dordrecht.

Dar R.A., Shahnawaz M. and Qazi P.H. 2017. General Overview of Medicinal Plants: A Review. The Journal of Phytopharmacology, 6(6), 349-351.

DEFF-RSA. 2020. Bio-prospecting Economy. Department: Environment, Forestry and Fisheries. Republic of South Africa. Retrieved 14 December 2020 from https://www.environment.gov.za/projectsprogrammes/bioprospectingeconomy 
Diaz-Reviriego I., Gonzalez-Segura L., Fernandez-Llamazarez A., Howard P.L., Molina J. and ReyesGarcia V. 2016. Social Organization Influences the Exchange and Species Richness of Medicinal Plants in Amazonian Home-gardens. Ecology and Society, 21, 1. http://dx.doi.org/10.5751/ES$\underline{07944-210101 .}$

Dzerefos C.M., Witkowski T.F. and Kremeh-Kohne S. 2016. Aiming for the biodiversity target with the social welfare arrow: Medicinal and other useful plants from a critically endangered grassland ecosystem in Limpopo Province, South Africa. International Journal of Sustainable Development and World Ecology, 24(1), 52-64.

Egamberdieva D., Wirth S., Behrendt U., Ahmad P. and Berg G. 2017. Antimicrobial Activity of Medicinal Plants Correlates with the Proportion of Antagonistic Endophytes. Frontiers in Microbiology, 8, 199, $1-11$.

Egamberdieva D. and Teixeira da Silva J.A. 2014. Medicinal Plants and PGPR: A New Frontier for Phytochemicals. In: Egamberdieva D., Shrivastava S., Varma A. (eds) Plant-Growth-Promoting Rhizobacteria (PGPR) and Medicinal Plants. Soil Biology. Springer, Cham. https://doi.org/10.1007/978-3-319-13401-7 14.

Fennel C.W., Light M.E., Sparg S.G., Stafford G.I., van Staden J. 2004. Assessing African medicinal plants for efficacy and safety: agricultural and storage practices. Journal of Ethnopharmacology, 95, 113121.

Giurgiu R.M., Morar G.A., Dumitras A., Boanca P., Duda B.M. and Moldovan C. 2014. Study regarding the suitability of cultivating medicinal plants in hydroponic systems in controlled environment. Research Journal of Agricultural Science, 46(2), 84-92.

Gurib-Fakim A. 2014. Novel plant bio-resources: Application in food, medicine and cosmetics. First edition, Wiley \& Blackwell. Oxford: United Kingdom.

Hishe M., Asfaw Z. and Giday M. 2016. Review on value chain analysis of medicinal plants and the associated challenges. Journal of Medicinal Plants Studies, 4(3), 45-55.

Innovus (Undated). Cultivation method for the medically valuable Pelargonium. Retrieved 15 December 2020 from https://www.innovus.co.za/technologies/medicine-and-health-1/phytomedicinesolutions/cultivation-method-for-the-medically-valuable-pelargonium.html

Jager A.K. and van Staden J. 2000. The need for cultivation of medicinal plants in Southern Africa. Outlook on Agriculture, 29(4), 283-284.

Kamatchi K.B. and Vigneswari R. 2018. A comparative study on elemental composition in some wild and cultivated medicinal plants. Annals of Plant Sciences. 7, 2418-2422

Kaur J., Kaur S. and Mahajan A. 2013. Herbal Medicines: Possible Risks and Benefits. American Journal of Phytomedicine and Clinical Therapeutics, 1(2), 226-239.

Keirungi J. and Fabricius C. 2005. Selecting medicinal plants for cultivation at Nqabara on the Eastern Cape Wild Coast, South Africa: Research in action. South African Journal of Science, 101(11-12), $497-501$.

Kumar S. and Bhatnagar T. 2014. Studies to Enhance the Shelf Life of Fruits using Aloe Vera Based Herbal Coatings: A Review. International Journal of Agriculture and Food Science Technology, 5(3), 211218. 
Kunwar R.M., Mahat L., Acharya R.P., Bussmann R.W. 2013. Medicinal plants, traditional medicine, markets and management in far-west Nepal. Journal of Ethnobiology and Ethnomedicine, 2013, 9, 24.

Lerotholi L., Chaudhary S.K., Combrink S. and Viljoen A. 2017. Bush tea (Athrixia phylicoides): A review of the traditional uses, bioactivity and phytochemistry. South African Journal of Botany, 110, 4-17.

Lubbe A. and Verpoorte, R. 2011. Cultivation of medicinal and aromatic plants for specialty industrial materials. Industrial Crops and Products, 34(1), 785-801.

Mahmoudi R. 2017. Application of medicinal plants: from past to present. MOJ Biology and Medicine. 1(3), 80. DOI: 10.15406/mojbm.2017.01.00016.

Maroyi A. 2017. Diversity of use and local knowledge of wild and cultivated plants in the Eastern Cape province, South Africa. Journal of Ethnobiology and Ethnomedicine, 13, 43. DOI 10.1186/s13002017-0173-8.

Marshall E. 2011. Health and Wealth from Medicinal Aromatic Plants. Diversification Booklet No. 17. Rural Infrastructure and Agro-Industries Division. FAO, Rome.

McGaw L., Jager A., Grace O., Fennel C. and van Staden J. 2005. Medicinal Plants. In: Van Niekerk A. (eds) Ethics in Agriculture - An African Perspective. Springer, Dordrecht. https://doi.org/10.1007/1-4020-2989-6 6

Mbuni Y.M., Wang S., Wang Q. et al. 2020. Medicinal Plants and Their Traditional Uses in Local Communities around Cherangani Hills, Western Kenya. Plants, DOI: 10.3390/plants9030331.

Moeng E.T. and Potgieter M.J. 2011. The trade of medicinal plants by muthi shops and street vendors in the Limpopo Province, South Africa. Journal of Medicinal Plants Research, 5(4), 558-564.

Mofokeng M.M., Sehlola D.M., Araya H.T., Amoo S.O. and du Plooy C.P. 2020. A new record of mealybugs (Paracoccus burnerae Brain - Hemiptera: Pseudococcidae) and leafhoppers (Mngenia angusta Theron - Cicadellidae: Coelidiinae) on a Southern African medicinal plant, Greyia radlkoferi. African Entomology, 28(2), 465-468.

Moshi M.J. and Mhame P.P. 2013. Legislations on medicinal plants in Africa. Medicinal Plant Research in Africa, 2013, 843-858.

Moyo M., Aremu O.A. and Van Standen J. 2015. Medicinal plants: An invaluable, dwindling resource in sub-Saharan Africa. Journal of Ethnopharmacology, 174, 595-606.

Ndou P., Taruvinga B., Mofokeng M.M., Kruger F., Du Ploy C.P. and Venter S.L. 2019. Value Chain Analysis of Medicinal Plants in South Africa. Ethno-Medicine, 13(4), 226-236.

Negi V.S., Kewlani P., Pathak R., Bhatt D., Bhatt I.D., Rawal R.S., Sundriyal R.C., Nandi S.K. 2018. Criteria and indicators for promoting cultivation and conservation of medicinal and aromatic plants in Western Himalaya, India. Ecological Indicators, 93, 434-446.

Netshiluvhi T.R. and Eloff J.N. 2016. Effect of water stress on antimicrobial activity of selected medicinal plant species. South African Journal of Botany, 102, 202-207.

Noorhosseini S.A., Fallahi E., Damalas C.A., Allahyari M.S. 2017. Factors Affecting the Demand for medicinal Plants: Implications for Rural Development in Rasht, Iran. Land Use Policy, 68(2017), 316-325. 
Nwafor C.U. and Westhuizen C. 2020. Prospects for Commercialization among Smallholder Farmers in South Africa: A Case Study. Journal of Rural Social Sciences, 35(1): Article 2. Available at: https://egrove.olemiss.edu/irss/vol35/iss $1 / 2$.

Ofori D.A., Obiri B.D., Gyimah A., Adam K.A., Jimoh S.O., Jamnadass R.H. 2012. Ethnobotany, propagation and conservation of medicinal plants in Ghana. Ghana Journal of Forestry, 28(1), 2938.

Oluwafemi R.A., Olawale A.I. and Alagbe J.O. 2020. Recent trends in the utilization of medicinal plants as growth promoters in poultry nutrition. Research in Agricultural and Veterinary Sciences, 4(1), 5-11.

Opara E.R. and Osayi K.K. 2016. Factors Affecting the Utilization of Herbal Medicine as a Livelihood Alternative among Residents of Imo State: The Role of Social Work Professionals. IOS Journal of Humanities and Social Science, 21(5), 66-78.

Panday A. and Singh S. 2016. Aloe Vera: A Systematic Review of its Industrial and Ethno-Medicinal Efficacy. International Journal of Pharmaceutical Research \& Allied Sciences, 5(1), 21-33.

Petersen L., Reid A.M., Moll E.J. and Hockings M.T. 2017. Perspectives of wild medicine harvesters from Cape Town, South Africa. South African Journal of Science, 113(9-10), retrieved 15 October 2020 from http://dx.doi.org/10.17159/sajs.2017/20160260.

Prinsloo G. and Nogemane N. 2018. The effect of water availability on chemical composition, secondary metabolites and biological activity in plants. Phytochemical Review, 17(4), 1-14. DOI:10.1007/s11101-018-9567-z.

Raghu A.V. and Amruth M. 2018. Cultivation of medicinal plants: Challenges and prospects. In: Raghu AV., Amruth, M. et al. (eds), Prospects in conservation of Medicinal Plants. KSCSTE-Kerala Forest Research Institute. India.

Rankoana S.A. 2016. Sustainable Use and Management of Indigenous Plant Resources: A Case of Mantheding Community in Limpopo Province, South Africa. Sustainability, 8, 221. DOI: $10.3390 /$ su8030221.

Rashid A.Z.M., Tunon H., Khan N.A. and Mukul S.A. 2014. Commercial Cultivation by Farmers of Medicinal Plants in Northern Bangladesh. European Journal of Environmental Sciences, 4(1), 60-68.

Rathore R. and Mathur A. Entrepreneurship Development in Medicinal and Aromatic Plants: Prospects and Challenges. International Journal of Economic Plants, 5(1), 32-35.

Rousan L.M and El-Uzaizi S.F. 2016 Farmer's knowledge level and training needs toward the production and conservation of medicinal herbal plants in Jordan. Journal of Medicinal Plants Research, 10(24), 351-359.

Sagbo I.J. and Mbeng W.O. 2018. Plants Used for Cosmetics in the Eastern Cape Province of South Africa: A Case Study of Skin Care. Pharmacognosy Reviews 12, 139-56.

Sanhokwe M., Mupangwa J., Masika P.J., Maphosa V. and Muchenge V. 2016. Medicinal plants used to control internal and external parasites in goats. Onderstepoort Journal of Veterinary Research, 83(1), a1016. Available at http://dx.doi. org/10.4102/ojvr.v83i1.1016.

Schippmann U., Leaman D. and Cunningham A. 2006. A Comparison of Cultivation and Wild Collection of Medicinal and Aromatic Plants under Sustainability Aspects. In, R.J. Bogers, L.E. Craker and D. Lange (eds.), Medicinal and Aromatic Plants, 75-95. Springer. Netherlands. 
Schippmann U., Leaman D.J., Cunningham A. 2002. Impact of cultivation and gathering of medicinal plants on biodiversity: Global trends and issues. Biodiversity and Ecosystem Approach in Agriculture Forestry and Fisheries, 2, 31-44.

SEDA- 2012. Research study to identify needs, opportunities and challenges of small and medium enterprises in the traditional medicine sector. Final Report, Atalanta Consulting. November 2012. Small Enterprise Development Agency.

Semenya S.S. and Potgieter M.J. 2014. Medicinal plants cultivated in Bapedi traditional healers' homegardens, Limpopo Province, South Africa. African Journal of Traditional, Complementary and Alternative Medicines, 11(5), 126-132.

Shakya A.K. 2016. Medicinal Plants: Future Source of New Drugs. International Journal of Herbal Medicine, $4(4), 59-64$.

Shengji P., Hamilton A.C., Lixin Y., Huyin H., Zhiwei Y., Fu G., Quangxin Z. 2010. Conservation and development through medicinal plants: A case study from Ludian (Northwest Yunnan, China) and presentation of a general model. Biodiversity Conservation, 19, 2619-2636.

Sher H., Aldosari A., Ali A. and de Boer H.J. 2014. Economic benefits of high value medicinal plants to Pakistani communities: an analysis of current practice and potential. Journal of Ethnobiology and Ethnomedicine, 10, 71. DOI: 10.1186/1746-4269-10-71

Sher H. and Bankworth M.E. 2015. Economic development through medicinal and aromatic plants (MAPs) cultivation in Hindu Kush Himalaya Mountains of District Swat, Pakistan. Journal of Mountain Science, 12. DOI: 10.1007/s11629-014-3247-2

Sher H., Busmann R., de Boer H.D. 2016. Traditional use of medicinal plants among Kalasha, Ismaeli and Sunni groups in Chitral District, Khyber Pakhtunkhwa province, Pakistan. Journal of Ethnopharmacology, Retrieved 5 August 2020 from https://doi.org/10.1016/i.jep.2016.04.059.

Strydom H.A. and King N.D. 2013. Fuggle and Rabie's Environmental Management. Second Edition. Juta, Clairmont (1142 pp.).

Tanga M., Lewu F.B., Oyedeji O.A. and Oyedeji O.O. 2018. Cultivation of Medicinal Plants in South Africa: A Solution to Quality Assurance and Consistent Availability of Medicinal Plant Materials for Commercialization. Academia Journal of Medicinal Plants, 6(7), 168-177.

Torri M.C., Herrmann T.M. 2011. Bridges between Tradition and Innovation in Ethnomedicine. Fostering Local Development through Community-Based Enterprises in India; Springer: Heidelberg, Germany. ISBN 978-94-007-1112-9.

Tshabalala T., Ncube B., Moyo H.P., Abdel-Rahman E.M., Mutanga O. and Ndhlala A.R. 2020. Predicting the spatial suitability distribution of Moringa oleifera cultivation using analytical hierarchical process modelling. South African Journal of Botany, 129, 161-168.

Van Wyk A.S. and Prinsloo G. 2018. Medicinal plant harvesting, sustainability and cultivation in South Africa. Biological Conservation 227, 335-342.

Volenzo T. and Odiyo J. 2020. Integrating endemic medicinal plants into the global value chains: the ecological degradation challenges and opportunities. Heliyon, 6(9), e04970. Retrieved 10 July 2020 from https://doi.org/10.1016/j.heliyon.2020.e04970.

Wiersum K.F., Dold A.P., Husselman M. and Cocks M. 2006. Cultivation of medicinal plants as a tool for bio-diversity conservation and poverty alleviation in the Amatola Region, South Africa. In, R.J. Bogers, L.E. Craker and D. Lange (eds), Medicinal and Aromatic Plants, 43-57. Springer: Netherlands. 
Williams S.J., Jones J.P., Annewandter R.A. and Gibbons J.M. 2014. Cultivation can increase harvesting pressure on overexploited plant populations. Ecological Applications, 24(8), 2050-2062.

Xego S., Kambizi L. and Nchu F. 2016. Threatened medicinal plants of South Africa: Case of the family hyacinthacea. African Journal of Traditional, Complementary and Alternative Medicines, 13(3), 169-180. 